\title{
René Girard's Reflections on Modern Jihadism: An Introduction
}

\author{
Andreas Wilmes \\ Centre de Recherche sur les Liens Sociaux \\ University Paris-Descartes, France
}

\begin{abstract}
This paper aims to offer a comprehensive overview of René Girard's reflections on the issue of modern jihadism. It addresses three key aspects of his reasoning: (I) the rise of Islamic terrorism in the context of a globalization of resentment; (II) modern jibadism understood as an "event internal to the development of technology;" (III) the hypothesis that modern jihadism "is both linked to Islam and different from it."
\end{abstract}

\section{Keywords}

René Girard; Jacques Ellul; Apocalypse; Islam; jihadism; Judeo-Christianity; mimetic theory; nonuse of power; suicide attacks; sacred; sacrifice; technology; terrorism.

"Christians understand that the Passion has rendered collective murder inoperative.

This is why, far from reducing violence, the Passion aggravates it.

Islamism seems to have understood this very quickly, but in the sense of jihad."

\section{René Girard}

\section{Introduction}

During his late career, René Girard had a growing concern for the contemporary threat of jihadism that he regarded as a "monstrous problem." He saw 9/11 as a "seminal event" representing "a new world dimension"2 because of which we must "radically change the way we think" (BE, 214). What is the nature of this unprecedented situation and to what

\footnotetext{
1 René Girard, Phil Rose, "A conversation with René Girard (August 2006/May 2007)”, Contagion: Journal of Violence, Mimesis, and Culture 18 (2011): 34.

2 René Girard \& Robert Doran, "Apocalyptic Thinking after 9/11: An Interview with René Girard". SubStance 37/1 (2008): 20-21.

3 René Girard, Battling to the End: Conversations with Benoit Chantre (East Lansing: Michigan State University Press, 2010), 214.

This is an Open Access article distributed in accordance with the Creative Commons Attribution Non Commercial (CC-BY-NC-ND 4.0) license, which permits others to copy or share the article, provided original work is properly cited and that this is not done for commercial purposes. Users may not remix, transform, or build upon the material and may not distribute the modified material (bttp:// creativecommons.org/ licenses/by-nc/4.0/)
} 
extent does it force us to renew our most common concepts and theories? This is the question that I would like to address in this paper.

It is certainly a tricky question. Girard never wrote a comprehensive essay on the issue of Islamic terrorism. Most of his remarks on this matter can be found in a series of interviews and in the epilogue of his last book, Battling to the End (BE, 211-217). In addition, Girard rarely introduces definitive statements, acknowledging that his hypotheses are still on an exploratory level. He did not see himself as an expert in the fields of Islamic and terrorism studies. Furthermore, he was cautious in his reasoning due to the lack of available data and academic research on the topic at the beginning of the 2000s. Girard frequently acknowledged that he regarded jihadist suicide attacks as a mysterious phenomenon. To him, modern jihadism was an enigma which needed to be urgently addressed, but which he never pretended to have completely resolved.

In this study, I do not debate on whether Girard's thoughts on modern jihadism are relevant or not. Neither do I try to link his theories to current events - Girard's observations mainly pertain to the terror attacks perpetrated by Al-Qaeda and never wrote on more recent phenomena such as the rise of Daesh. Eventually, a critical discussion of his stances on Islam would also go beyond the scope of my paper which intends to be descriptive. ${ }^{4}$

I have directed my efforts towards collecting Girard's statements on jihadism from various sources, and towards confronting and comparing these statements in order to outline the structure and key elements of his reflexions. Although Girard sometimes hesitates in his remarks and often raises questions which remain unsolved (i.e. is modern jihadism more of a political or religious phenomenon? To what extent does it deform traditional Islam? Do suicide attacks belong to a peculiar psychology or can we explain them in more general terms?), I shall contend here that his reasoning articulates three ideas: (I) Islamic terrorism as the symptom of "a mimetic rivalry on a planetary scale;" (II) modern jihadism understood as an "event internal to the development of technology" (BE, 215); (III) modern jihadism defined as "both linked to Islam and different from it" (BE, 215). These three ideas are not only complementary, but they also show the development of a reasoning moving from the most basic principles to a more comprehensive account of the complexity of modern jihadism.

\section{I. "What is occurring today is a mimetic rivalry on a planetary scale"}

Contrary to Samuel Huntington, Girard contends that the roots of modern violence and conflict do not rest on civilizational difference but on appropriative mimesis. By bringing people closer together, globalization is far from introducing a new era of peace and harmony: it intensifies the convergence of desires and thus rivalries on a planetary scale. To this extent, jihadists, even if they are not aware of it, are driven by their desire for the West. It is through the unconscious dynamic of mimetic desire that jihadists covet the same type

\footnotetext{
${ }^{4}$ For critical and up-to-date approaches on Islam and Girard's mimetic theory, I suggest readers to refer to the excellent volume edited by Wolfgang Palaver and Richard Schenk, Mimetic Theory and World Religions (East Lansing: Michigan State University Press, 2018). Different perspectives on Islam and religion can also be found in the other contributions to the thematic dossier.
} 
of lifestyle, values and political hegemony as westerners. And it is through the same dynamic that jihadists will encounter the resistance of their model. In the end, the Western obstacle became the target of an extreme resentment which led to the tragedy of 9/11. However, this is only a limited and somehow inaccurate account of Girard's discussions on modern jihadism.

There is no doubt that Girard was struck by the planetary dimension of Osama bin Laden's ideology. In his public statements, Bin Laden compares the undiscriminating attacks on Palestinian, Lebanese and Iraqi populations with the US atomic bombings of Hiroshima and Nagasaki. ${ }^{5}$ America and its western allies appear as the evil incarnation of "global economy" imposing "unbelief and humiliation" on the poor "with its military force." There is an aim to avenge victims which goes beyond the geographical and historical limits of the Ummah. As Girard puts it:

When I read the first documents of Bin Laden and verified his allusions to the American bombing of Japan, I felt at first that I was in a dimension that transcends Islam, a dimension of the entire planet. Under the label of Islam we find a will to rally and mobilize an entire third world of those frustrated and of victims in their relations of mimetic rivalry with the West. ${ }^{7}$

Far from being a purely "defensive jihad" with the demarcated objective of fighting against American occupation and military forces, Bin Laden's project presents itself as a crusade against what he points out to be global domination, injustice and "unbelief." It is this move from a defensive to a global jihad which Girard's mimetic theory helps analyze. From AlQaeda's perspective, the American military interventions and political commitments express claims over given territories which are part of the holy land of Arabia. At this stage, mimetic rivalry directly concerns the object that the opponent (that is, the model of desire) seemingly aims to acquire. But the US, due to their economic, technological and military superiority, soon become an obstacle in these territorial claims. Faced with this modelturned-obstacle, jihadist soldiers will unconsciously lose sight of the initial object of rivalry in favour of an increasing fascination for their main opponent. The dynamic of mimetic rivalry reaches a further stage in which the "desire to acquire ... quickly degenerates into ... metaphysical desire, whereby the subject seeks to acquire the being of his or her model." $(B E, 31)$. This obsession for the model-obstacle of desire is the turning point: from this point, the desire for the model's being constantly escalates with the model's resistance.

\footnotetext{
5 "They came to fight Islam and its people on the pretext of fighting terrorism. Hundreds of thousands, young and old, were killed in Japan, the most distant land - but this is not a war crime, just an issue to be looked into.". Osama bin Laden, Messages to the World: The Statements of Osama bin Laden (New York: Verso, 2005), 105. In a letter issued in 2002, Bin Laden states: "However, history will not forget the war crimes that you [Americans] committed against the Muslims and the rest of the world; those you have killed in Japan, Afghanistan, Somalia, Lebanon, and Iraq will remain a disgrace that you will never be able to escape." ibid., 169. For other allusions to the atomic bombing of Japan in Bin Laden's statements see ibid., 51; 66-67; 168.

${ }^{6}$ Ibid., 150.

${ }^{7}$ René Girard, Evolution and Conversion: Dialogues on the Origin of Culture (New York: Continuum International Publishing, 2008), 238. See also René Girard \& Henri Tincq, "What is Occuring Today Is a Mimetic Rivalry on a Planetary scale".
} 
From this point, "sentiments, defeated, bounce back as re-sentment." 8 Feelings of entitlement alternate with feelings of incompleteness. The initial opponent eventually turns into an absolute enemy, that is to say an obstacle which needs to be destroyed. Americans, in Bin Laden's words, are the "soldiers" or "allies" of "Satan." A delimited conflict turns into a global crusade in which the enemy's destruction becomes the sole matter.

However, it is important to see that mimetic theory is not an all-purpose explanation which could always be applied in the same way and regardless of any context. For instance, what does Girard mean when he states that "Terrorism is the vanguard of a general revenge against the West's wealth"10 (BE, 211)? Does he mean that modern jihadism is the mere symptom of a modern and global class struggle? His standpoint is more complex. Although major economic inequalities are experienced by third world populations, the fact is that the masses are powerless: the western model of financial and personal success remains out of reach. The masses belong to the context of external mediation in which the distance between the subjects and the model of desire is too significant to cause mimetic contagion. The situation is quite different for someone like Bin Laden who grew up in a rich Saudi Arabian family and had some actual knowledge of the western way of life. Bin Laden not only had time to dwell on his feelings of humiliation in face of the economic and technological superiority of the West, but he was also closer to the western model than the masses. In this respect, Girard draws a parallel between Bin Laden and Mirabeau who, as a noble, was rejected by his own milieu and eventually supported the French Revolution out of resentment. ${ }^{11}$ The context of internal mediation, in which the short distance (intellectual, social, economic, geographical) between the subject and the model of desire tends to produce mimetic contagion, is the common feature of Bin Laden and Mirabeau. Therefore, it is necessary to keep in mind the difference between social class distinctions and distinctions pertaining to external and internal mediation. Inequalities in wealth and power are a crucial factor to the extent that they are liable to and can even be rightly perceived by members of the third world elite, such as Bin Laden, as humiliating signs of western arrogance. ${ }^{12}$ As we shall see in the second part of the paper, these inequalities are also important to understand modern jihadism's mimetic response to Western's technological superiority.

It is worth considering now how mimetic contagion manifests itself in this context of internal mediation. In Girard's view, imitation is often "unconscious" in the sense of

\footnotetext{
${ }^{8}$ Elisabetta Brighi, "The mimetic politics of lone-wolf terrorism", Journal of International Political Theory 11/1 (2015): 151.

${ }_{9}$ Osama bin Laden, Messages to the World: The Statements of Osama bin Laden, $61 ; 161 ; 180$.

10 Girard also states that "Islamism is only one symptom of a trend to violence that is much more global. It comes less from the South than from the West itself because it takes the form of a response of the poor to those who are well-off." (BE, 211). As shown by his conversations with Robert Doran, he maintained this reasoning till the end of his career: "(...) the accumulated wealth in the West as compared with the rest of the world is a huge scandal, and ... 9/11 s not unrelated to this fact." René Girard \& Robert Doran, “Apocalyptic Thinking after 9/11: An Interview with René Girard”, 23.

11 René Girard, Evolution and Conversion: Dialogues on the Origin of Culture, 238. See also René Girard \& Henri Tincq, "What is Occuring Today Is a Mimetic Rivalry on a Planetary scale".

12 Girard states that "The West is going to exhaust itself in its fight against Islamic terrorism, which Western arrogance has undeniably kindled." (BE, 209-210). Emphasis mine.
} 
"unwitting."13 On the one hand, the rivals aim to differentiate themselves. On the other hand, they are unaware that various attitudes depend on their unconscious desire to acquire the model's being. Behind the rivals' will to differentiate from one another, an external observer will be able to find that intellectual and behavioural imitation betrays their common pretence of being different. In this sense, it is necessary to look at a "deeper level" where "imitation prevails." 14 . How does this apply to jihadism?

Unquestionably, for Girard, globalization equals westernization. ${ }^{15}$ Thus, the "global jihad" will somehow appear as an "impoverished opposite" 16 of the western model. In Bin Laden's statements, "individuals" and "nations" are "on the same level:" 17 values of justice and equality transcend national boarders to such an extent that, as Scott Cowdell observes, a "victimary rhetoric" seems to emerge "within a newly unified global consciousness." 18 It is well-known that Girard outlined the Christian and western origins of the modern concern for victims in I See Satan Fall Like Lightning. Although our capacity to deconstruct scapegoat mechanisms finds its origin in the Judeo-Christian revelation, we mostly tend to ignore this fact and use this knowledge with bad faith and in a competitive manner:

The victims most interesting to us are always those who allow us to condemn our neighbours. And our neighbours do the same. They always think about victims for whom they hold us responsible. [...] In our world ... we are all bombarding each other with victims... ${ }^{19}$

This instrumentalization of the concern for victims through mimetic rivalry becomes a very real and destructive phenomenon in the case of contemporary jihadism. One of the most obvious functions of the terror attack is to remind the enemy of the victims and damages he had caused. And this brutal reminder is brought by "soldiers of Allah" who turn themselves into martyrs. In other words, modern jihadism functions like a "super-victimary machine:" 20 its internal logic is an extreme self-victimization in solidarity with victims for the killing of

13 René Girard \& Mark R. Anspach, "A response: Reflections from the perspective of mimetic theory”, Terrorism and Political Violence 3/3 (1991): 143.

14 René Girard \& Mark R. Anspach, "A response: Reflections from the perspective of mimetic theory", 144.

15 In an interview for La Croix, Girard states: "There are indeed only Western values, all the rest is folklore". René Girard, "What are our Values Worth? (2002)", The Philosophical Journal of Conflict and Violence 1/2 (2017).

16 René Girard \& Mark R. Anspach, "A response: Reflections from the perspective of mimetic theory", 144.

17 René Girard, "What are our Values Worth? (2002)".

18 Scott Cowdell, René Girard and Secular Modernity (Notre Dame, Indianna: University of Notre Dame Press, 2013), 150.

${ }^{19}$ René Girard, I See Satan Fall Like Lightning (New York: Orbis Books, 2001), 164.

20 "You can foresee the shape of what the Anti-Christ is going to be in the future: a super-victimary machine that will keep on sacrificing in the name of the victim." René Girard, Evolution and Conversion: Dialogues on the Origin of Culture, 236. Girard scholars frequently stress this victimization aspect in respect to modern terrorism. See for instance Espen Dahl, "Girard on Apocalypse and Terrorism", in The Cambridge Companion to Religion and Terrorism, ed. James R. Lewis (Cambridge: Cambridge University Press, 2017), 89-101. For an approach more focused on the issue of religious fundamentalism, see Wolfgang Palaver, "The Ambiguous Cachet of Victimhood: On Violence and Monotheism", in The New Visibility of Religion, eds. Michael Hoelzl and Graham Ward (London: Continuum, 2008), 68-87. 
other and multiple victims. In this light, it is interesting to notice that although Bin Laden frequently refers to the lex talionis, he is also concerned about justifying the $9 / 11$ attacks by their supposedly less inhumane nature than the US military operations in the Middle East. To him, the killing of innocent victims requires the vindication of a higher victim-status than the enemy:

As for the World Trade Center, the ones who were attacked and who died in it were part of a financial power. It was not a children's school! Neither was it a residence. And the general consensus is that most of the people who were in the towers were men that backed the biggest financial force in the world, which spreads mischief throughout the world. ${ }^{21}$

The fact that Girard was struck by Bin Laden's "allusions to the American bombing of Japan," shows that he identified a victimary and mimetic outbidding at work in modern jihadism. According to him, Bin Laden is "a modern man influenced by Western values."22 By this, he means that, on a deeper level, behind the fundamentalist and religious discourse, we find typical thought patterns of the westernized and globalized world in which national borders become mere abstractions, individuals or groups claim for the same type of personal success and instrument the concern for victims in a spirit of competition.

Other signs of mimetic contagion can be found in the behaviour and attitudes of jihadi soldiers. For instance, in the epilogue of Battling to the End, Girard observes:

Atta, the leader of the September 11 group who piloted one of the two airplanes, was the son of a middle class Egyptian family. It is staggering to think that during the last three days before the attack, he spent his nights in bars with his accomplices. There is something mysterious and intriguing in this. (BE, 212)

As noticed by Johnathan Raban, Mohamed Atta and his accomplices "left a forensic spur of brand names across the length and breadth of the United States." Prior to the attacks, the jihadists were actually best known "as efficient modern consumers." 23 The "intriguing" aspect stressed by Girard most probably rests on this conspicuous alternation of attraction and repulsion - typical of the ambivalent feelings in the context of internal mediation towards the West which is here directly and almost objectively evidenced by the terrorists' behaviour. Similarly, he mentions the "idea of 'sleeper cells" in which the jihadist's fascination and hatred for the western model-obstacle takes an even more extreme dimension (BE, 212).

Eventually, imitation prevails in the jihadi soldiers' modus operandi. The tragedy of 9/11 was made possible by a certain technical achievement from Al-Qaeda which went unnoticed by American homeland security. As Girard puts it: "But by their effectiveness, the

\footnotetext{
${ }^{21}$ Osama bin Laden, Messages to the World: The Statements of Osama bin Laden, 119.

22 René Girard, "What are our Values Worth? (2002)".

23 Jonathan Raban, "My Holy War", The New Yorker (February 4, 2002), https://www.newyorker.com/magazine/2002/02/04/my-holy-war (accessed November 21, 2017). This newspaper article is also discussed and quoted in Scott Cowdell's René Girard and Secular Modernity, 151.
} 
sophistication of the means they employed, the knowledge that they had of the United States and their training, were not the authors of the [9/11] attack in a sense at least partly American?" ${ }^{24}$ These remarks lead us to the issue of technology which I shall address in the second part of this paper.

\section{II. "Islamism ... is a kind of event internal to the development of technology"}

Technology is one of the major moving forces of globalization of which, as we just saw, Girard paints a rather bleak picture. But, more importantly, technology has refined men's means of destruction. This not only implies that modern weapons could potentially extinguish life on earth, but also that states - provided that the technological means are at their disposal - can intervene in international conflicts without encountering resistance due to distance in space and time, due to the material characteristics of borders and territories or due to the direct confrontation of soldiers with the adversary on the battlefield. Aerial weapons and precision-guided munitions have erased the former physical limitations of war.

In this light, jihadists are at the same time significantly different from their western enemies in terms of technological means, while also significantly similar to them in terms of tactical aims. The method of suicide attack operations shows that an important symmetry prevails on the deepest level of the asymmetric conflict. For terrorists, the moral justification of the tactical use of aerial and smart weapons (i.e. exclusively targeting the adversaries' military forces and sparing the lives of civilians) merely appears as a piece of western rhetoric. This "moral" difference seems to them superfluous to the extent that new military technologies do not necessarily avoid collateral damage. In addition, they consider the western distinction between combatants and non-combatants as a luxury made possible by the sophistication of their enemies' technology. To put it another way, they state that this distinction only exists for the "rich" and the "well armed" and "that it does not reflect the power disparity." 25 What matters then for jihadists is to counter the technological superiority of the West in the most effective way. ${ }^{26}$ In this respect, the modus operandi of the suicide attack tends to erase the former physical limitations of warfare similarly to the tactical use of smart weapons but by other means. Despite its tactical disadvantages, the jihadi soldier, determined to turn technology against himself and against the anonymous

\footnotetext{
${ }^{24}$ René Girard, Evolution and Conversion: Dialogues on the Origin of Culture, 238. See also René Girard \& Henri Tincq, "What is Occuring Today Is a Mimetic Rivalry on a Planetary scale". After the publication of Battling to the End, Girard reiterates this observation in a more affirmative way: "Getting back to mimetism and the suicide bombers of 9/11: in their effectiveness, in their knowledge of the United States, their training conditions, they were a bit American ...". See René Girard, "I would like to be your age (2008)", The Philosophical Journal of Conflict and Violence 1/2 (2017).

25 Paul Dumouchel, "Suicide Attacks: Military and Social Aspects", in The Ambivalence of Scarcity and Other Essays (East Lansing: Michigan State University Press, 2014), 304. Dumouchel's paper is an excellent study on the issue of modern terrorism and western technology in terms of mimetic rivalry. It is also remarkably close to some of Girard's thoughts on this issue in Battling to the End and in his last interviews.

26 "But terrorism is the only possible form of war in the face of technology." René Girard \& Robert Doran, "Apocalyptic Thinking after 9/11: An Interview with René Girard”, 22.
} 
crowd into which he melts, imitates the damage potential and sophistication of western weapons. Suicide attackers, "like smart weapons, can identify their targets, even track them if necessary." They "replace assault helicopters and remote-controlled rockets by determined pedestrians." 27 As Girard observes, we are "gradually led into increasingly asymmetrical conflicts and 'surgical' wars, which are the mimetic doubles of the terrorist carnage we experience today." (BE, 91).

This is a decisive aspect because Girard not only contends that "politics have been overtaken by technology" (BE, 40) but also that codified war is about to disappear. Clausewitz's theoretical conception of war taken as a duel with no internal limits tends to become a historical reality. In the end, modern jihadism clearly appears as the symptom of an "escalation to extremes" revolving around the technological superiority of the West. ${ }^{28}$ However, as Girard notices, this new reality goes beyond the understanding of both Western and Islamic world:

Today's terrorism is new, even from an Islamic point of view. It is a modern effort to counter the most powerful and refined tool of the Western world: technology. It counters technology in a way that we [westerners] do not understand, and that classical Islam may not understand either. (BE, 214)

As Girard sees it, the problem is that neither Western humanism nor Islam is capable to recognize the extreme escalation of the phenomenon due to the loss of efficiency of the self-regulating mechanisms of human violence. Western humanism sacralises technology and therefore does not recognize that the global spread of violence only comes from men (who are increasingly deprived of their sacrificial safeguards). According to Girard, Islam does not recognize this phenomenon either, because of its ambiguous attitude towards archaic violence.

First, what about the West? Girard's first important remarks on technology date back to the end of the 1970s. In Things Hidden Since the Foundation of the World (1978), he draws a parallel between the sacrificial systems of primitive religions and the atomic bomb, stating that both are containing violence by means of violence. ${ }^{29}$ In primitive religions, myths and rituals are generated through the blind and collective mechanism of scapegoating putting an end to the mimetic crisis. The surrogate victim, who has been simultaneously perceived by the violent crowd as responsible for the crisis and for its resolution, is the hidden origin of the seemingly contradictory features of the sacred. To put it differently, primitive divinities appear at the same time as beneficial and monstrous because they stem from the unconscious sacralization of the victim of the founding murder. Just like primitive divinities, the atomic bomb is both monstrous and beneficial insofar as its potential catastrophic damages also constitute an existential threat which seems to put an internal limit on men's tendencies of mutual-aggression. There is, however, a major difference: while in primitive religions the containment of human violence is resting on superstitions pertaining to rituals

${ }^{27}$ Paul Dumouchel, "Suicide Attacks: Military and Social Aspects", 303.

28 As Girard puts it: "The trend towards undifferentiation has been strengthened by the West's technological and military means." (BE, 39-40).

${ }^{29}$ René Girard, Things Hidden Since the Foundation of the World (London: Bloomsbury, 2016), 243-251. 
and prohibitions, the atomic bomb is a scientific fact. In primitive religions, men do not know that the sacred proceeds from an externalization of their own violence. In the case of nuclear weapons, men know they are the creators of their mass destruction tools. Nonetheless, as Dupuy observes, the nuclear menace is also a violence that humanity projects out of itself - such as earthquakes and tsunamis, although in a more destructive form, it appears to us "like an exceeding dangerous entity, external to us" and "whose intentions toward us are not evil." 30 In Girard's own words, the nuclear age represents an "intermediary" situation ${ }^{31}$ between primitive religions and the Judeo-Christian revelation inasmuch as the reality of human violence is neither simply hidden by myths, nor completely acknowledged.

In a nutshell, the western sacralization of technology rests on the process of men objectifying their violence in weapons to protect themselves against their own violence. In the light of this, it is worth considering that Girard thinks that the Cold War has been "superseded both in scope and importance" 32 by the current conflicts opposing the West to global jihadism. According to him, the former division between the Western and Eastern blocs represented an opposition "inside humanism." 33 This is not meant to deny the violence and atrocities which occurred during this period, but to stress that the oppositions between the two blocs were pertaining to different conceptions and ideals of man's material well-being. In addition, the Western bloc and Eastern bloc were similar in their reliance on technology. The nuclear threat was hanging over the heads of the world's leaders and seems, in retrospect, to have prevented the global catastrophe of mutual destruction (i.e. what we usually call "nuclear deterrence"). However, suddenly, with the rise of modern jihadism we are back "in archaic religion-but with modern weapons." 34 Jihadists aim to counter the technological superiority of the West in a mimetic way. But this mimetic rivalry is embodied within a religious project in which technology is desacralized. Especially with regard to suicide attacks, technology no longer appears as the objectification of human violence aimed at protecting men against their own violence, ${ }^{35}$ but as a subordinate component of sacrifices made in the name of Allah. Modern jihadism appears as a frightening and mysterious phenomenon to us inasmuch that it radically breaks with the western model of technology taken as a sacrificial protection. As shown by Girard's

30 Jean-Pierre Dupuy, "The Nuclear Menace - A new Sacrament for Humanity: Catastrophes and Near Misses", in Apocalypse Deferred: Girard and Japan, ed. Jeremiah Alberg (Notre Dame, Indiana: University of Notre Dame Press): 33.

${ }^{31}$ René Girard, Things Hidden Since the Foundation of the World,

32 René Girard \& Robert Doran, «Apocalyptic Thinking after 9/11: An Interview with René Girard», 28.

${ }^{33}$ Ibid., 29.

${ }^{34}$ Ibid., 28.

35 "Let us recall the last pages of Victor Hugo's The Legend of the Ages which feature aviation bringing peace to the world. This trick was recently repeated when we were told that computers defeated the Soviets and communism. Facing Bin-Laden, the opposite is true: we are confronted by people who settle in America, who become sufficiently American to function in the context of American life and who then, all of a sudden, start crashing airplanes into towers. Technology turns against an America that so believed in the goodness of man!" René Girard, "What are our Values Worth? (2002)". "Another example of the apocalyptic atmosphere is 9/11: for the first time, men have turned technology against themselves." René Girard, "I would like to be your age (2008)". 
comments in 2007-2008, this feature of modern jihadism raises prominent issues of concern. Westerners do not really know "if there will appear something [like] the rapid industrialization in the Muslim world" 36 and of which extent jihadists might take advantage. We also do not know if, instead, jihadists might more directly "try to win on the basis of population growth and the fascination they exert." 37 Because jihadism is using technology for "radical, metaphysico-religious ends," 38 its way of functioning goes beyond the understanding of western humanism.

Like many of his contemporaries, Girard followed events such as the arrest and conviction of José Padilla and was aware of Al-Qaeda's will to build and acquire nuclear weapons. According to him, the possible use of dirty bombs for terroristic ends ${ }^{39}$ shows that jihadists no longer consider the superiority of technological threats as an internal limit to conflict - unlike the leaders of the Soviet Union who, as he observes, backed down during the Cuban missile crisis because they "knew that they would lose an atomic war." (BE, 69).

We are confronted with the return of religion and archaic violence. But for what kind of religion are jihadi soldiers fighting for? I will address this question in the remainder of this paper.

\section{Modern jihadism "is both linked to Islam and different from it"}

I shall start with Girard's general perspective on the status of resentment and religion in Islamic terrorism and will, at first, put aside his specific remarks pertaining to the Qur'an. What remains unquestionable in Girard's thoughts on modern jihadism is the fact that resentment shall be considered as a necessary rather than a sufficient cause. As Girard puts it: "Modern resentment never leads all the way to suicide" (BE, 215). In resentment, the increasing fascination for the model-obstacle of desire can become an unbearable reality which the subject could aim to destroy. Resentment may well explain cases in which the adversary's defeat matters more than having a stunning and personal victory over him. But suicide attackers exclude themselves from the world of the living: they follow their model-obstacle into death. In his first comments on 9/11, Girard suggests interpreting suicide attacks as an extreme form of resentment. ${ }^{40}$ However, he clearly distances himself from this first interpretation in further writings and interviews. How can we explain this change of perspective? At the end of the 2000s, Girard came to the conclusion that interpreting

\footnotetext{
36 René Girard \& Robert Doran, “Apocalyptic Thinking after 9/11: An Interview with René Girard, 23.

${ }^{37}$ Ibid., 23.

38 Ibid., 28.

39 As noticed by Girard: "The next step will consist in acquiring dirty bombs containing nuclear waste. It even seems that American technicians are working for terrorists without knowing it, and now building pocket-sized atomic bombs." (BE, 67). A few pages later, he adds: "Who are the new kamikazes who will soon have miniaturized nuclear weapons in their hands, and who, in compliance with the principle of pure reciprocity, will use them without any rules, reviving ancient divisions and inventing new ones?" (BE, 69).

${ }^{40}$ See especially René Girard \& Henri Tincq, "What is Occuring Today Is a Mimetic Rivalry on a Planetary scale" \& René Girard, "What are our Values Worth? (2002)".
} 
jihadism exclusively in terms of a non-avowed fascination for the West could be "too excessive." ${ }^{41}$ The fact that jihadists aim to challenge the technological superiority of the West introduces a dimension which goes beyond mere envy. Girard observes that Islamic terrorists may think that western weapons are "terribly dangerous" but that westerners appear as "weak" people whose "civilization" could be "easily destroyed." 42 He also adds that "Consumerism has no hold on those who engage in these suicide attacks." 43 Furthermore, from the perspective of mimetic theory, desire always obeys an unconscious strategy consisting in perpetuating itself through the quest of illusory differences and modelobstacles. In this respect, dying so that the model-obstacle of desire dies would not make any sense ${ }^{44}$ unless jihadists are convinced to die as "martyrs" - that they are convinced to make themselves self-sufficient and absolutely different from their victims or, in other words, sacred in their own death. Eventually, jihadism does not simply equal modern nihilism under a religious guise. Even in 2001 during his interview for Le Monde, in which he lays a strong emphasis on the resentment interpretation, Girard states: "It is evident that in the Muslim world, the kamikaze terrorists embody models of saintliness." 45 A few years later (2007-2008), he explains to Doran that a more satisfactory explanation of suicide attacks should be focused on the interplay between jihadists' resentment and their religious ends. ${ }^{46}$

But Girard mainly outlines a working hypothesis. Although he states that mimetic theory should investigate the interplay between resentment and religion, this investigation does not appear in his writings. A similar observation pertains to Girard's reflections in the epilogue of Battling to the End. The global context of the end of codified war goes beyond the Islamic world but is at the same time exploited by terrorists referring to the Islamic law. It would therefore be necessary to inquire into the interplay between the disappearance of war as an institution and the cultural and religious features of the Islamic world. As Girard puts it: "We have to be able to think about both Islamism and the escalation to extremes at the same time; we need to understand the complex relations between these two realities." (BE, 215). But, again, this research project is only outlined and raises questions to which no definitive answers can be found in Girard's work.

However, some general perspectives on Islam and terrorism can be identified. It is conspicuous that Girard neither states that modern jihadism has nothing to do with Islam, nor that modern jihadism should simply be perceived as a traditional Islamic phenomenon. Modern jihadism, in his own words, "is both linked to Islam and different from it." (BE, 215).

I will first address the question of why modern jihadism and traditional Islam should be distinguished. In the epilogue of Battling to the End, we find the statement that "[Today's]

${ }^{41}$ René Girard \& Robert Doran, “Apocalyptic Thinking after 9/11: An Interview with René Girard, 23.

42 Ibid., 23. Girard even adds that this way of thinking "may not be totally wrong"

43 Ibid., 22.

44 "For us, it makes no sense to be ready to pay with one's life for the pleasure of seeing the other die." (BE, 214).

${ }^{45}$ René Girard \& Henri Tincq, "What is Occuring Today Is a Mimetic Rivalry on a Planetary scale".

${ }^{46}$ René Girard \& Robert Doran, "Apocalyptic Thinking after 9/11: An Interview with René Girard, $22-23$. 
terrorism is something new that exploits Islamic codes but does not at all belong to classical Islamic theory." (BE, 214). In 2001, Girard was wondering whether the politico-religious model of martyrdom implemented by jihadists belongs to traditional Islam or not. ${ }^{47}$ But shortly after this first interview, he clearly differentiates the method of suicide attack operation from the Islamic tradition: "(...) in the case of "frenzied" Islamists, it is quite obvious that the Qur'an, with the possible exception of the famous sect of the Assassins, has scarcely ever been interpreted in this way." 48 Although Girard never formulated a comprehensive theory on suicide attacks, he situates this phenomenon in the context of the globalization of resentment and the duel opposing Islamic terrorists to western technology, a context which certainly contributes to bending Islamic tradition.

In his writings and interviews, Girard frequently refers to the Islamic interpretation of Abraham's sacrifice of Isaac. For instance, during his interview for Le Monde:

Islam has also formidable prophetic insights about the relation between the crowd, the myths, victims, and sacrifice. In the Muslim tradition, the ram Abel sacrificed is the same as the one God sent to Abraham so that he could spare his son. Because Abel sacrificed rams, he did not kill his brother. Because Cain did not sacrifice animals, he killed his brother. In other words, the sacrificial animal avoids the murder of the brother and the son. That is, it furnishes an outlet for violence. Thus, Mohammed had insights which are on the plane of certain great Jewish prophets.... ${ }^{49}$

The Qur'an contains the idea that sacrifice provides men shelter from their own violence. Far from being purely barbaric, the substitution of a human with an animal victim shows a mechanism aimed to appease and divert man's violence. The Muslim Eid al-Adha, commemorating the killing of the animal who spared Isaac's life, is therefore a yearly reminder of the protective function of sacrifice. What occurs in the case of terrorism inspired by religious fundamentalism is a perversion of the original aims of sacrifice. This can already be observed during the 1980s in the first significant emergence of suicide attacks in the Middle East under the auspices of Hezbollah. The commemoration of Husayn ibn Ali's death during the Ashura is an important event for the majority of the Shia Muslims. Even when the Ashura implies bloody self-flagellation rituals (which is not always the case), sacrifice still plays its protective role by redirecting violence against oneself instead of against one's neighbour. In the light of this, Hezbollah's tactical use of suicide bombing

47 "You die as a martyr in order to be copied and thus manifest a project of transforming the world politically. Applied to the beginning of the 21st century, a model like this leaves me aghast. Does it really belong to Islam?" René Girard \& Henri Tincq, "What is Occuring Today Is a Mimetic Rivalry on a Planetary scale".

48 René Girard, "Facing the Devil's Test: The Truth According to René Girard (2005)", The Philosophical Journal of Conflict and Violence 1/2 (2017). See also René Girard, "What are our Values Worth? (2002)": "One of the major features of 'ressentiment' is that one prefers to lose provided the other loses as well. In the case of the kamikaze, this is pushed to the extreme. Islam is not, however, quite the same thing." Emphasis mine.

${ }^{49}$ René Girard \& Henri Tincq, "What is Occuring Today Is a Mimetic Rivalry on a Planetary scale". These remarks on the interpretation of sacrifice in Moslem tradition can already be found in René Girard, Violence and the Sacred (Baltimore: Johns Hopkins University Press, 1977), 4-5. 
radically diverts sacrifice from its initial function. Self-martyrdom becomes a weapon which no longer contains the spread of violence. As noticed by Girard and Anspach:

When Hezbollah's leading cleric called on believers to abandon selfflagellation in favour of resistance to the foreigner, struggle against the self was ... transformed into struggle against the other. What is reversed here is the direction in which the violence is channelled, the direction of the sacrifice. 50

The question then is not so much to naively point out violent or peaceful features in religion but to discover why religion may suddenly fail to contain violence. Girard states that modern jihadism "would not have taken such a hold on people's minds if it did not bring up to date something that has always been present in Islam" (BE, 213). He believes in the possibility of a historical regression in which the archaic features of Islam, freed from their sacrificial safeguards, return in our modern world in the form of the jihad. Nowadays, sacrifice proves less and less effective in containing violence by means of violence. This aspect is certainly evidenced by the escalation to extremes between Jihad and the West. However, for Girard, the increasing sterility and violence of sacrificial mechanisms must foremost be put into perspective with the Judeo-Christian Revelation. The Passion of Christ reveals what has been hidden through the myths of primitive religions: the collective murder of an innocent victim lies at the origin of the sacred. This radical reversal of the foundations of culture gradually deprives men of their self-regulating mechanisms of violence. From then, the meaning of history becomes apocalyptic: human violence unleashed by the loss of sacrificial safeguards may reach the point of no return of global chaos and destruction.

In the light of this, what kind of problems does Girard identify in Islam? According to him, Islam is a hybrid religion which combines Judaeo-Christian and archaic features. ${ }^{51}$ In his interviews, he frequently states that Islam is the Judaeo-Christian revelation minus the Cross. ${ }^{52}$ As already shown in the remarks on the Islamic reference to animal sacrifice in the story of Abraham and Isaac (Surah 37: 83-114), the Qur'an does contain Judaeo-Christian elements. Girard also acknowledges that the Qur'an, just like the Bible, offers intuitions on mimetic rivalry and, contrary to archaic religions, sides with innocent victims (although he does not refer to specific passages of the Qur'an, an evident illustration is Surah 12 which re-narrates the biblical story of Joseph proved innocent against his accusers and persecutors). However, as he puts it: "the main drama," namely Jesus' crucifixion, "is missing." 53 Girard even states that "The Qur'an sees the Christian Passion as an intolerable

${ }^{50}$ René Girard \& Mark R. Anspach, "A response: Reflections from the perspective of mimetic theory", 145. Emphasis mine. Girard maintains this idea in his last book when he defines suicide attacks as "a monstrous inversion of primitive sacrifices" (BE, 67).

51 "It [Islam] would be an archaic religion strengthened by aspects of the Bible and Christianity" (BE, 214).

52 See: René Girard \& Henri Tincq, "What is Occuring Today Is a Mimetic Rivalry on a Planetary scale". René Girard \& Wolfgang Palaver, "The Bloody Skin of the Victim", in The New Visibility of Religion, eds. Michael Hoelzl and Graham Ward (London: Continuum, 2008), 64-65. René Girard, "René Girard's Accusation: Intellectuals are the Castrators of Meaning", Modern Age 50/2 (2008): 184.

${ }^{53}$ René Girard \& Wolfgang Palaver, "The Bloody Skin of the Victim”, 65. 
form of blasphemy." ${ }^{54} \mathrm{He}$ read several translations of the Qur'an and it is not risky to conjecture that he implicitly refers to the verses 156-159 of Surah 4:

- and because they disbelieved and uttered a terrible slander against Mary, and said, "We have killed the Messiah, Jesus, son of Mary, the Messenger of God."They did not kill him, nor did they crucify him, though it was made to appear like that to them; those that disagreed about him are full of doubt, with no knowledge to follow, only supposition: they certainly did not kill bim - God raised him up to Himself.

God is almighty and wise. ${ }^{55}$

This absence of Jesus's death on the cross in the Qur'an has been interpreted in several ways by Islamic studies. Some state that Jesus was substituted for a different person during the crucifixion, others that the persecutors mistook Jesus' fainting on the cross for his actual death, yet others that His crucifixion did occur but that as a spiritual being He could not have physically died during this event. In any case, these standpoints on the Passion of Jesus are in contradiction with what Girard sees as the cornerstone of his religious anthropology, that is the hypothesis that Christ's crucifixion and resurrection reveal the violent origins of human culture.

In Battling to the End, Girard suspects that "a comparative approach" of biblical and Qur'anic texts "would reveal that" the latter contain "no real awareness of collective murder" (BE, 216). An important aspect of his interpretation of the Christian Passion is the separation between the violence of the crowd striking upon Jesus and His resurrection on the third day. On the one hand, men are shown equal in respect to their participation at the persecution and to their propensity for violence. On the other hand, it is not the collective murder which makes the victim sacred. With Christ's resurrection, a new form of sacred emerges which is bound to the revelation of man's violence and the forgiveness of his sins. This is why the Bible is at the same time a clear-cut revelation of human violence and a limpid deconstruction of archaic religion. However, the Islamic attitude towards violence is less clear. For the Christian Passion does not solely concern God's defence of innocent victims, but also God's consent to suffer for man's violence which is to be revealed and forgiven. In this respect, the Qur'anic revelation of violence remains incomplete. As Girard observes: "Islam excludes the possibility that God could accept to suffer." ${ }_{56}$

Girard had a lot of admiration for Jacques Ellul's theological writings, especially What I Believe which he considered to be a masterpiece. Ellul had an extremely negative view of Islam and it is uncertain to what extent Girard shared his standpoints. ${ }^{57}$ However, Girard

\footnotetext{
${ }^{54}$ Ibid., 65.

55 The Qur'an, trans. M.A.S. Abdel Haleem (Oxford: Oxford University Press, 2005), 65. Emphasis mine. This excerpt may be compared to other English translations. My only intention here is to give readers an idea of what Girard refers to.

${ }^{56}$ René Girard \& Wolfgang Palaver, "The Bloody Skin of the Victim”, 65.

57 I would nonetheless like to raise a question. A polemical chapter in Ellul's The Subversion of Christianity argues that the idea of medieval Christian crusades was at first a conflictual imitation of the jihad. The subversion is twofold: Christianity should never have been an instrument of political power and should never have imitated Islam. I wonder if Ellul had in mind Girard's theory of mimetic rivalry when he wrote this chapter. I also wonder if Girard had Ellul's book in mind when he writes: "In fact, we can wonder to what extent the excesses of the Crusades in the thirteenth century were not mimetic
} 
agreed with Ellul that the Bible and the Qur'an are not referring to the same God. He especially mentions Ellul's idea that the God of Islam is different from the Christian God of "non-power." This notion does not imply that the Christian God is powerless, but that God chooses to renounce his power. For Ellul, God's "nonuse of power" (non-puissance) is inseparable from the fact that he leaves men responsible and free. His creation is indispensable because He cares for it: He is God "incarnate in love" who "suffers from our sin." 58 Although Christ could use His divine power, He refuses to manifest it through miracles. In this respect, one of the clearest examples is His refusal to work the miracle that His persecutors ask of Him: "If you want us to believe in you, come down from the cross" (Matthew 27:40)..$^{59}$ In this sense, the cross appears as one of the strongest symbols of the "nonuse of power." On the contrary, for Ellul, Allah appears as "a radical and absolutely self-sufficient God," "imperturbable and immutable" who "does his will for no consideration for anyone or anything" 60 and whose mercifulness is that of an absolute sovereign. Girard endorsed this theological standpoint:

For Islam, God is essentially power. There is a great distance between the people and the omnipotent God. With Ellul, I would argue that Christianity shows us a God of non-power, something very different even from nonviolence. God chooses not to use the power he has but instead to leave humanity free. The question is whether people will be capable of exercising this freedom. ${ }^{61}$

For Girard, the problem is that a God of power who cannot accept to suffer for humanity's sins is a God who cannot leave men fully responsible and free in face of their own violence. In the Qur'an, contrary to the Bible, the disclosure of the victims' innocence does not go hand in hand with the disclosure of men's universal propensity to persecute. Christian conversion involves experiences such as the ones of Saints Peter and Paul "who discovered that they were themselves guilty of persecution and confessed their own guilt

responses to the Jihad, of which we are now suffering the consequences in Europe and the Middle East." (BE, 41) \& "However, the Crusades are not as important as Islam thinks. The Crusades were an archaic regression without consequences for the essence of Christianity." (BE, 215). Compare with Jacques Ellul, The Subversion of Christianity (Eugene, Oregon: Wipf and Stock, 2011), 95-112.

58 Jacques Ellul, What I Believe (Grand Rapids, Michigan: William B. Eerdmans, 1989), 179.

59 Ibid., 150. That is not to say that Ellul denies Jesus's miracles. He rather states that His miracles mainly pertain to love instead of power (e.g. even when Jesus calms the tempest, He does so to restore "peace and confidence" among His disciples). Going back to the question of the cross, in Islam and Judeo-Christianity, Ellul writes: "We know in the Gospels that Jesus pushes his love to its limit and after a tough spiritual fight accepts his death on the cross. However, in the Koran, it is unthinkable that he, whose power is his primary manifestation, should be crucified." See Jacques Ellul, Islam and JudeoChristianity (Eugene, Oregon: Wipf and Stock, 2015), 30. This posthumous manuscript was published in France in 2001. We do not know if Girard read it. However, it is obvious that Girard and Ellul had the same concern about the status of the crucifixion in the Qur'an. According to Ellul, Surah 4: 156159 states that Jesus was substituted for another person during the crucifixion. However, we saw that other interpretations have been attributed to the verses. Contrary to Ellul, Girard does not refer to a specific interpretation.

${ }^{60}$ Jacques Ellul, What I Believe, 179.

61 René Girard, “A Conversation with René Girard”, The Ellul Forum 35 (2005): 20. 
rather than that of their neighbours." 62 According to Girard, the constant Christian "dialectic between the victim and the persecutor" "does not exist" in Islam."63 Consequently, the Qur'an leaves room for a defence of victims based on claims of moral purity and superiority: "As in Christianity, Islam rehabilitates the innocent victim, but it does so in a militant Way." ${ }^{4}$ In this respect, Girard is also concerned about the use of the concept of tahrif by some Muslim scholars which tends to legitimate the idea that Christians and Jews would have falsified or deformed the scriptures. This betrays an attitude of opposition and resentment which, as he observes, precludes the possibility of a constructive interfaith dialogue: "Seeing Jews and Christians as falsifiers is the most irremediable thing. It allows Muslims to eliminate all serious discussion, any comparison among the three religions." (BE, 215-216).

Only "The Cross ... puts an end to the ancient and violent myths." ${ }^{5}$ Christianity shows that only two types of sacrifice exist: archaic sacrifice (that is, sacrifice of others) and selfsacrifice. However, the "nonuse of power" embodied by Jesus' self-sacrifice is rejected by the Qur'an. Accordingly, Girard thinks that Islam does not comprehensively deconstruct ancient myths and that its attitude towards sacrifice remains unclear. While Islam undoubtedly contains biblical elements, it does not completely prohibit archaic sacrifice. ${ }^{66}$ In addition, Islam's attitude towards the archaic cannot give way to an apocalyptic conception of history. By this, Girard means that the apocalypse cannot be conceived as the unleash of man's violence deprived of his sacrificial recourses. It does not confront man to the urgent responsibility of the complete dismissal of sacrifice in favour of self-sacrifice. On the contrary, in "Islam, if you are violent you are inevitably an instrument of God. Thus, it is really saying that the apocalyptic violence comes from God." ${ }^{67}$ Eventually, Girard seems to believe that residual archaic elements can be found in Islam's relation to death ${ }^{68}$ but it is not clear to what he exactly refers. Does he think that the Qur'an conceives death as

\footnotetext{
62 René Girard, I See Satan Fall Like Lightning, 164.

${ }^{63}$ René Girard, "René Girard's Accusation: Intellectuals are the Castrators of Meaning”, 184.

${ }^{64}$ Ibid., 184. See also René Girard \& Henri Tincq, "What is Occuring Today Is a Mimetic Rivalry on a Planetary scale".

65 Ibid., 184.

66 Ibid., 184.

${ }^{67}$ René Girard \& Robert Doran, “Apocalyptic Thinking after 9/11: An Interview with René Girard”, 29. Girard also states that "The problem with the Christian fundamentalists, though not as much as with the Muslims, is their view of the violence of God". René Girard, "Ratzinger is Right", New Perspectives Quarterly 22/3 (2005): 48.

68 "Islam's mystic relationship with death makes death even more mysterious." René Girard, "René Girard's Accusation: Intellectuals are the Castrators of Meaning”, 184. See also René Girard \& Henri Tincq, "What is Occuring Today Is a Mimetic Rivalry on a Planetary scale". For a different approach, see Rüdiger Lohlker, "Islam: Law and Violence (And Nonviolence)", in Mimetic Theory and World Religions, 413-426. Lohlker observes that, in Islamic tradition, "Death is not seen as a witness for the truth of god." (422). From this perspective: (1) Jesus cannot die on the cross for the expiation of humanity's sins; (2) there would be little if no evidence for the sacralization of death in the Qur'an. Accordingly, contrary to what Girard seems to argue, the Qur'anic standpoint on the crucifixion does not necessarily imply a "mystical relationship with death".
} 
divinely willed? Does he have in mind some much debated verses such as Surah 3: 169$171{ }^{69}$ In the end, his remarks are too elusive to give way to solid conjectures.

It is significant that Girard was especially careful in respect to the issue of jihad and death. He was aware that the stakes and risks related to this question were high. He knew that insufficiently documented or verified links between jihadi suicide attacks and Islam's relation to death would have amounted to a "fraudulent propaganda against Muslims" (BE, 215). He also knew that ready-made psychological explanations of suicide attacks would have risked caricaturing his anthropology. Instead, he defined modern jihadism as a complex phenomenon at the intersection of globalization, resentment, technology, and archaic religion. What we do not know is whether Girard thought to have identified the essential parts of the "super-victimary machine" of modern jihadism or was searching for further elements of explanation...

\section{Conclusion}

Whether one agrees or not with Girard's critique of Islam, it would be inaccurate to state that, in the end, he unwillingly endorsed the idea of a clash of civilizations. As I hope to have shown, mimetic rivalry is the main moving force even if it is embodied within sociocultural differences. It is also interesting to notice the peculiarity of Girard's defence of Christianity. According to him, the conflict between the West and the Jihad is an opposition between the sacralization of technology and a warlike religion. This means that, on both sides, the conflict rests on a subversion of Christianity. On the one hand, the Western world enslaved Christianity by transforming it into a pure means of material comfort, by accepting to objectify its violence in weapons and to live under their protection. On the other hand, Jihadism interprets the apocalyptic revelation as godly messages for the holy war - which is, by definition, a limitless war with no declarations, no treatises, no national borders, no peace. For Girard, Christianity introduces a distinct perspective insofar as it is bound to the consciousness that violence is essentially human.

\section{References}

The Qur'an. Translated by M.A.S. Abdel Haleem. Oxford: Oxford University Press, 2005.

Bin Laden, Osama. Messages to the World: The Statements of Osama bin Laden. New York: Verso, 2005.

Brighi, Elisabetta. “The mimetic politics of lone-wolf terrorism”. Journal of International Political Theory 11/1 (2015): 145-164.

Cowdell, Scott. René Girard and Secular Modernity. Notre Dame, Indianna: University of Notre Dame Press, 2013.

\footnotetext{
69 "[Prophet], do not think of those who have been killed in God's way as dead. They are alive with their Lord, well provided for, happy with what God has given them of His favour; rejoicing that for those they have left behind who have yet to join them there is no fear, nor will they grieve; [rejoicing] in God's blessing and favour, and that God will not let the reward of the believers be lost.". The Qur'an, 47. For an interesting demythologization of these verses, see again Rüdiger Lohlker, "Islam: Law and Violence (And Nonviolence)", 421-423.
} 
Dahl, Espen. "Girard on Apocalypse and Terrorism”. In The Cambridge Companion to Religion and Terrorism, ed. James R. Lewis, 89-101. Cambridge: Cambridge University Press, 2017.

Dumouchel, Paul. "Suicide Attacks: Military and Social Aspects". In The Ambivalence of Scarcity and Other Essays, 301-318. East Lansing: Michigan State University Press, 2014.

Dupuy, Jean-Pierre. "The Nuclear Menace - A new Sacrament for Humanity: Catastrophes and Near Misses". In Apocalypse Deferred: Girard and Japan, ed. Jeremiah Alberg (Notre Dame, Indiana: University of Notre Dame Press): 19-40.

Ellul, Jacques. Islam and Judeo-Christianity (Eugene, Oregon: Wipf and Stock, 2015

. What I Believe. Grand Rapids, Michigan: William B. Eerdmans, 1989. . The Subversion of Christianity. Eugene, Oregon: Wipf and Stock, 2011.

Girard, René. Violence and the Sacred. Baltimore: Johns Hopkins University Press, 1977. . The Scapegoat. Baltimore: John Hopkins University Press, 1986. . I See Satan Fall Like Lightning. New York: Orbis Books, 2001. . "What is occurring Today is a Mimetic Rivalry on a Planetary Scale". Le Monde (November 6, 2001). Tr. Jim Williams.

https://www.uibk.ac.at/theol/cover/girard/le_monde_interview.html (accessed November 21, 2017). . "A Conversation with René Girard". The Ellul Forum 35 (2005): 19-20. . "Ratzinger is Right". New Perspectives Quarterly 22/3 (2005): $42-48$. . Evolution and Conversion: Dialogues on the Origin of Culture. New York: Continuum International Publishing, 2008. . “Apocalyptic Thinking after 9/11: An Interview with René Girard”. SubStance 37/1

(2008): 20-32. . "René Girard's Accusation: Intellectuals are the Castrators of Meaning". Modern Age 50/2 (2008): 180-185.

. Battling to the End: Conversations with Benoit Chantre. East Lansing: Michigan State University Press, 2010. . “A conversation with René Girard (August 2006/May 2007)”. Contagion: Journal of

Violence, Mimesis, and Culture 18 (2011): 23-38. . Things Hidden Since the Foundation of the World. London: Bloomsbury, 2016. . "What are our Values Worth? (2002)". The Philosophical Journal of Conflict and Violence

$1 / 2$ (2017). "Facing the Devil's Test: The Truth According to René Girard (2005)". The Philosophical Journal of Conflict and Violence $1 / 2$ (2017).

. "I would like to be your age (2008)". The Philosophical Journal of Conflict and Violence $1 / 2$ (2017).

Girard, René \& Anspach, Mark R. "A response: Reflections from the perspective of mimetic theory". Terrorism and Political Violence 3/3 (1991): 141-148.

Girard, René \& Palaver, Wolfgang. "The Bloody Skin of the Victim”. In The New Visibility of Religion, eds. Michael Hoelzl and Graham Ward, 59-67. London : Continuum, 2008.

Palaver, Wolfgang. "The Ambiguous Cachet of Victimhood: On Violence and Monotheism". In The New Visibility of Religion, eds. Michael Hoelzl and Graham Ward, 68-87. London : Continuum, 2008. 
René Girard's Reflections on Modern Jihadism

Palaver, Wolfgang \& Schenk, Richard, ed. Mimetic Theory and World Religions East Lansing: Michigan State University Press, 2018.

\section{Abbreviations}

BE: Girard, René. Battling to the End. East Lansing: Michigan State University Press, 2010 